LOFT TECHNICAL REPORT LTR 1310-8 Rev. B NOVEMBER 14, 1978

\title{
CAPABILITY OF LOFT VITAL BATTERIES TO SUPPLY \\ EMERGENCY POWER DEMANDS DURING SEVERE COLD \\ WEATHER CONDITIONS
}

J. A. Yeates

THIS REVISION COMPLETELY SUPERSEDES ALL PREVIOUS ISSUES OF LTR 1310-8.

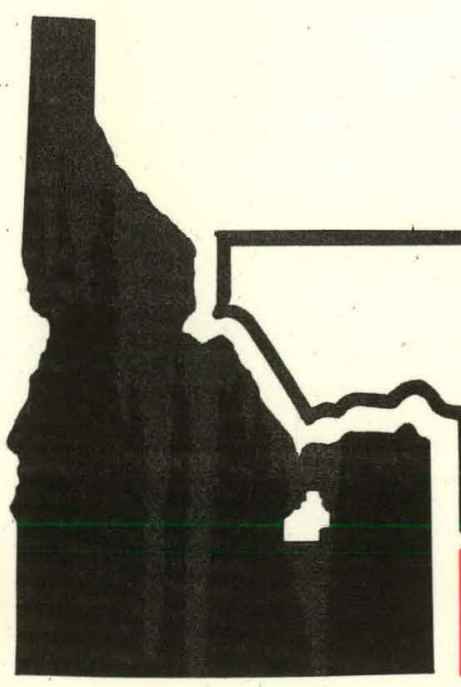

\section{$\prod_{F G \Sigma} E$ Idaho, Inc.}

IDAHO NATIONAL ENGINEERING LABORATORY

\section{DEPARTMENT OF ENERGY}




\section{DISCLAIMER}

This report was prepared as an account of work sponsored by an agency of the United States Government. Neither the United States Government nor any agency Thereof, nor any of their employees, makes any warranty, express or implied, or assumes any legal liability or responsibility for the accuracy, completeness, or usefulness of any information, apparatus, product, or process disclosed, or represents that its use would not infringe privately owned rights. Reference herein to any specific commercial product, process, or service by trade name, trademark, manufacturer, or otherwise does not necessarily constitute or imply its endorsement, recommendation, or favoring by the United States Government or any agency thereof. The views and opinions of authors expressed herein do not necessarily state or reflect those of the United States Government or any agency thereof. 


\section{DISCLAIMER}

Portions of this document may be illegible in electronic image products. Images are produced from the best available original document. 
LTR 1310-8

Reb. B

Page 1 of 13

\subsection{INTRODUCTION}

The LOFT vital batteries "A" \& "B" each consists of 129 submarine cells and are housed in Building. TAN 629. These batteries provide redundant sources of electrical power for vital MG sets A \& B which in turn power the 480 volt AC class IE, PPS loads. The building is unheated* and the batteries may be subject to very cold temperatures during winter conditions resulting in a reduction in their output capability. This report presents evidence of the temperatures to which the batteries may be subjected and evaluates the derating factors which are applicable to this installation. : The report compares the expected electrical load with the battery capacity and evaluates the time interval during which the batteries can supply the required vital loads at a temperature of $5 \mathrm{~F}$.

\subsection{NECESSITY FOR A COLD TEMPERATURE ANALYSIS}

In order to determine the cold temperature to which the batteries might be subjected, special data was recorded during the period Jan. 1 to Jan. 14, 1974. This data consisted of readings of air temperatures adjacent to the batteries recorded at $0830 \mathrm{hrs}$. and $1600 \mathrm{hrs}$. each day. It was noted that the lower temperatures occurred at $0830 \mathrm{hrs}$. In Fig. 1. these temperatures are plotted together with a companion plot of the official outside minimum temperatures for the TAN area.

The minimum inside air temperature observed was $-30 \mathrm{~F}$. It is presumed credible that with longer sustained perlods of $-30^{\circ} \mathrm{F}$. outside temperature the inside air temperatures and the electrolyte temperatures in turn could lower to the range of $-5^{\circ} \mathrm{F}$ to $\$ 10^{\circ} \mathrm{F}$. Such possibiliates dictate a need to analyze the limits of the battery capability in the event such temperature conditions are approached.

\subsection{ELECTRICAL LOAD DATA}

From LTR 1310-13 two electrical AC load conditions are noted as being applicable to the vital MG-Battery power sources.

a. The inttlal load is the load which would be automatically assumed by the MGs immediately following loss of commerclal power and which could continue up to 30 minutes. The load analysis in the LTR 131013 shows this load could reach $293 \mathrm{kw}$. This load is considered the MG load which must be used for this temperature analysis. Allowance for MG losses (15\%) increases this value to $345 \mathrm{kw}$ load on the battery.

b. Following the initial 30 minute period, trimming of non PPS loads from the vital $480 \mathrm{~V}$-bus will reduce the $M G$ loading to $135 \mathrm{KW}$. No analysis is made using this value.

*Office trailers have been installed in Bldg TAN 629 and will furnish incidental heat. The amount of heat is not considered significant compared to the heat d'issipation through the large roof. 
LTR 1310-8

Rev. B

Page 2 of 13

\subsection{BATTERY DERATING FACTORS}

The analysis considers three derating factors which can affect the batteries during cold temperature emergency use.

a. A derating to 80 percent of nominal capacity (5016 Ampere Hours) is used for allowable deterioration due to age and usage. This is the maximum permissible deterioration of capacity as indicated in Section 4.7 of the LOFT Technical. Specifications. This $80 \%$ factor appears in Column 10 of Table I.

b. A derating equal to 1000 ampere hours of discharge' is considered here to show the effects of a trickle discharge during normal operation. In percentage of rated capacity this derating factor varies from 13 to 18 percent depending on the discharge time for which the capacity rating is selected. The battery capacity is computed with and without this derating and is shown in Column 5 of Tab. I.

It is the: recommendation of the Gould Battery Company that the batteries be operated at a slight trickle or float charge, with that companys' assurance that the thick plate construction of this model cell prevents it from loss of capacity resulting from such operation. Thus, except for some unforseen loss of capacity during plant operation, the 13 to 18 percent derating is apt applicable and its inclusion in this analys is is provided only for information purposes.

c. The percent temperature derating of the battery operating time at $5^{0} \mathrm{~F}$ is shown in Fig. 2 for discharge at the $3 \mathrm{hr}$. rate (418kw) and the $8 \mathrm{hr}$. rate $(200 \mathrm{kw})$.

Fig 2 is the key figure and basis for the conclusions of this report. It is redrawn from Curve EB 6792 furnished by Gould, Inc. This curve was derived from tests af Exide Co. stationary storage batteries and is included as Appendix A of this LTR. It is important to note that the test batteries used to derive curve EB 6792 had a specific gravity of 1.210, whereas submarine type batteries have specific gravities in excess of 1.265 thus greatiy improving the gold temperature capacity. Curve EB 6792 was chosen for this analysis because it is noted that the cold temperature derating for batteries is more severe for conditions where load is held constant effecting a reduced operating time than oonditions where load (discharge amps), are reduced to permit the rated operating time. EB 6792 reflects the first condition.

The use of this Fig. 2 is discussed in Par. 5.0- "Analysis and Application of Derating Factors". 
LTR $1310-8$

Rev. B

Page 3 of 13

\subsection{ANALYSIS AND APPLICATION OF DERATING FACTORS} EMERGENCY LOAD VALUES

L.TR 1310-13 projects an AC load of $247 \mathrm{kw}$ for one half hour on Bus and recommends verification of this amount by actual load test. In response, so 68.02 Attachment 6 was performed using a load of $250 \mathrm{kw}$. However, some loads from Vital Bus B were necessarily connected in order to obtain this value and it is believed doubtful if in actual emergency conditions the loat. value of $250 \mathrm{kw}$ would be reached. LTR $1370-13$ also projects that new DAVDS loads will increase the peak loading to $293 \mathrm{kw}$. This value is used throughout this analysis even though it is considered an extremely unlikely load. With reference to Par. 3, $b$ above the factor of energy conservatism is:

$$
\frac{293 \mathrm{kw} \times 1 \mathrm{hr}}{293 \mathrm{~kW} \times \frac{1}{2} \mathrm{hr}+135 \mathrm{kw} \times \frac{3}{2} \mathrm{hr}}=1.37
$$

\section{VITAL MG LOSSES}

A recent review of vital MG input and output values indicated the combined losses of the $D C$ and $A C$ machine to be $15 \%$ at 75 to $100 \%$ of rated load. Thus an $A C$ load of $293 \mathrm{kw} \mathrm{AC}$ requires a battery output of $345 \mathrm{kw} \mathrm{DC}$. These conservative values are used as basis of the analysis.

DIESEL GENERATOR STARTING TIME

LOFT Technical Specification Par 4.7 .3 (2) (d) states that the time required for diesel generators to start and assume loads shall not exceed one hour. Hence the vital batteries must carry the vital loads for this one hour period following a commercial power outage.

\section{DETERMINATION OF TEMPERATURE DERATING}

To allow maximum. conservatism a vital bus $A C$ load of $293 \mathrm{kw}$ is assumed which corresponds to $345 \mathrm{kw}$ DC output from the battery. By interpolation, using Fig. 4 , this is equivalent to a $4 \mathrm{hr}$. discharge time rate.

The required energy for $\mathrm{l}$ hour is then $345 \mathrm{kw} \mathrm{hr}$.

Again using Fig. 4 as an aid for interpolation, the design capacity at the $4 \mathrm{hr}$. rate is $1380 \mathrm{kw} \mathrm{hr}$. Allowing $80 \%$ for deterioration gives $1100 \mathrm{kw} h \mathrm{hr}$. present capacity. Permissable combined derating of dis-

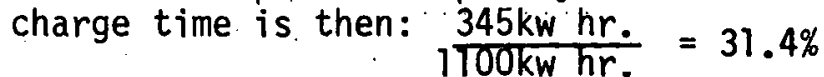

From Fig. 2, the minimum temperature for this derate is $2^{\circ} \mathrm{F}$. 


\section{Caloulation of Total Time Derating Factor}

In order to develop Table I and Figure 3, showing Battery discharge load vs Discharge time, the value of $50 \mathrm{~F}$ is selected as a lower operating temperature limit. Column 9 of Table I shows the temperature derating factors at $5^{\circ} \mathrm{F}$ for various $\mathrm{KW}$ loads determined from Fig. 2. Column 9 shows the total derate factor, and column 11 shows the resulting available hours of operation at $5^{6} \mathrm{~F}$.

Throughout Table I data is shown for a condition in which 1000 ampere hours of prior trickle discharge is considered. This condition is al so shown on Fig. 3 .

Curve No. 1 of Fig. 3 is noted to show the load point of $293 \mathrm{kw} \mathrm{AC}$ power and shows capability for operation for $1: 2$ hours. Because of the high degree of conservatism in selection of electrical loads, duration of loads and derating of the battery, the actual operating time is without doubt greater than this value. Curve No. 2 reflects the prior use of 1000 Ampere hours and is shown for information only.

\section{Recommendations}

a. If is recommended that during cold temperature conditions (ëlectrolyte temperatures less than $2 \theta^{\circ} \mathrm{F}$ ) the state of charge of the batteries be observed and maintained at a near full charge condition.

\section{Conclusions}

The vital batteries as rated are adequate to sustain all PPS loads for a period of more than one hour. 
FIG. 1.

TEMPERATURE DATA AT TAN.

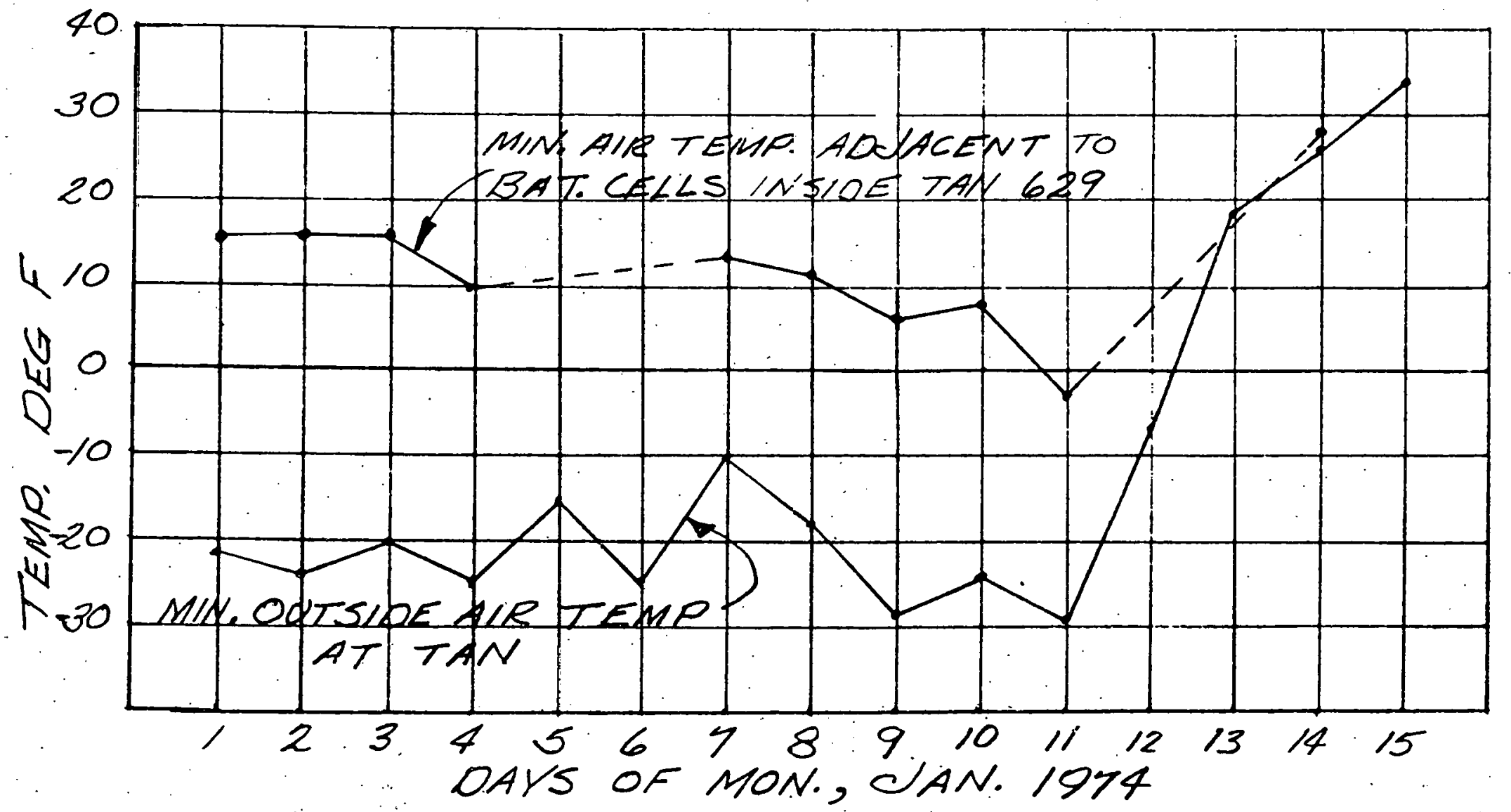

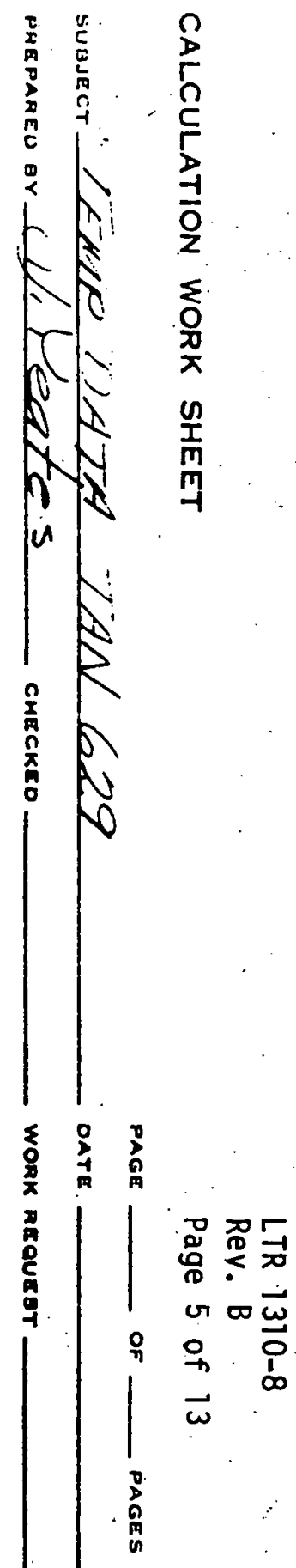


OHO NATIONAL ENGINEERING LABORATORY

FORM INEL-1692
(AOV. 476)

CALCULATION WORK SHEET

LTR 1310-8

Rev. $B$

Page 6 of 13

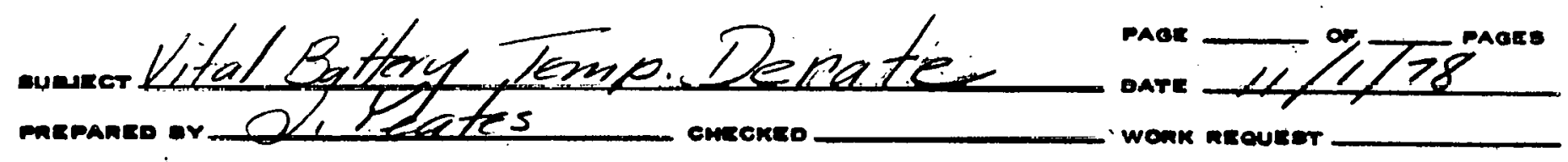

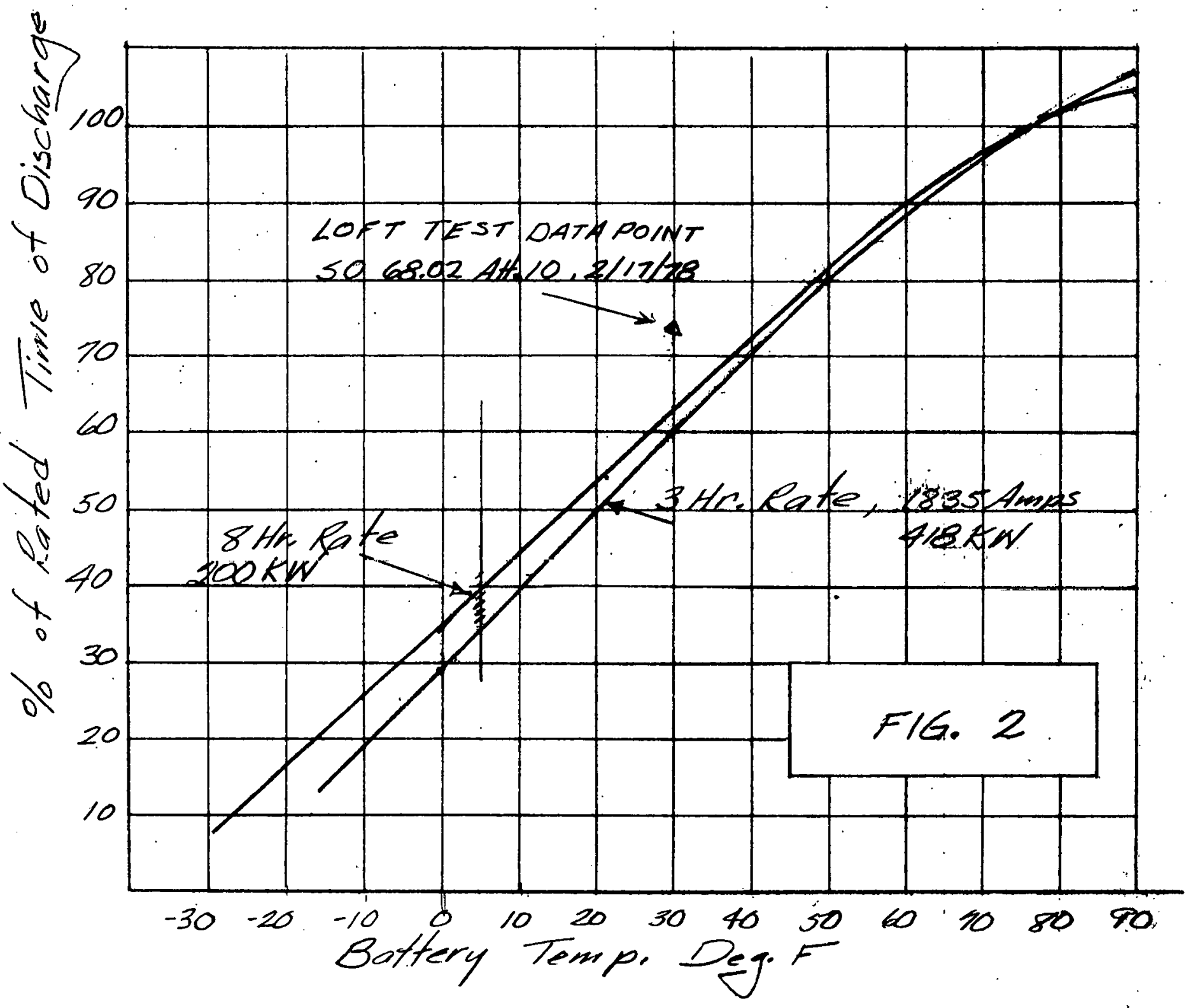

Note: Thisis a reproduction of Curve E8.6792 Furnished by Gould Co. It illustrates how the time period of discharge to "175 volts per cell is reducedlbycold. Temp.

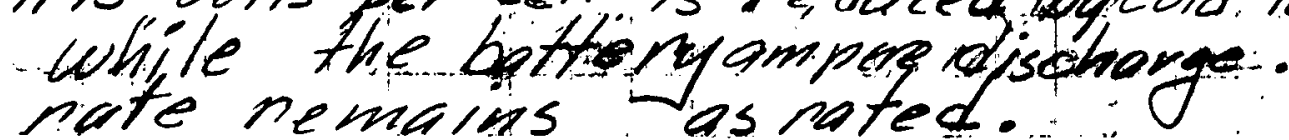


TABLE I

CALCULATION OF. VITAL BATTERY OPERATING TIME FOR VARIOUS DISCHARGE RATES AT $50^{\circ} \mathrm{F}$

\begin{tabular}{|c|c|c|c|c|c|c|c|c|c|c|c|c|c|}
\hline $\begin{array}{l}\text { Line } \\
\text { No. }\end{array}$ & \begin{tabular}{l}
1 \\
\multicolumn{1}{c}{1} \\
Nom. \\
Discharce \\
-ime \\
Hrs. \\
iGould \\
Data)
\end{tabular} & \begin{tabular}{l}
\multicolumn{1}{c}{2} \\
Rated. \\
Discharge \\
Amps \\
Gould \\
Data
\end{tabular} & \begin{tabular}{l}
\multicolumn{1}{c}{3} \\
Rated \\
Output \\
Amp Hrs. \\
$\quad$ Gou:d \\
Data
\end{tabular} & $\begin{array}{l}\text { 4 } \\
\text { Amp Hrs. } \\
\text { Minus } .1000 \\
(3)-1000\end{array}$ & $\begin{array}{l}{ }^{5} \\
\% \text { A.H. } \\
\text { Remaining } \\
\frac{(4)}{(3)}\end{array}$ & $\begin{array}{l}\quad 6 \\
\text { Rated } \\
\text { Batty } \\
\text { Output } \\
\text { KN } \\
\text { Gould } \\
\text { Data }\end{array}$ & $\begin{array}{l}\quad 7 \\
\text { Rated } \\
\text { Batt'y } \\
\text { Caṕcy } \\
\text { KWHR } \\
(6) \times(1)\end{array}$ & \begin{tabular}{l}
\multicolumn{1}{c|}{8} \\
$M G$. \\
$A C$ \\
Load \\
$\mathrm{KW}$. \\
$(6) \times .85$
\end{tabular} & $\begin{array}{l}\quad 9 \\
\text { Temp } \\
\text { Derate } \\
\text { Factor } \\
\text { for } 5{ }^{\circ} \mathrm{F} \\
\text { Fig } 2\end{array}$ & $\begin{array}{l}\quad 10 \\
\text { Total } \\
\text { Derate } \\
\text { Factor } \\
.8 \times(5) \times(9)\end{array}$ & $\begin{array}{l}\quad 11 \\
\text { Derated } \\
\text { Op. } \\
\text { Hrs } \\
(10) \times(1) \\
\end{array}$ & $\begin{array}{l}\quad 12 \\
\text { Batty } \\
\text { Capcy } \\
\text { at } \\
50 F \\
\text { KWhr } \\
(10) \times(7)\end{array}$ & $\begin{array}{l}13 \\
M G \\
\text { Output } \\
\text { KWHR } \\
(11) \times(8)\end{array}$ \\
\hline 1 & 3 & 1835 & 5505 & 4505 & 81.8 & 418 & 1255 & 356 & .34 & .223 & .67 & 280. & 238 \\
\hline 2 & 3 & 1835 & 5505 & - & 100 & 418 & 1255 & 356 & .34 & .272 & .815 & .331 & 290 \\
\hline 3 & 5 & 1220 & 6100 & 5100 & 83.6 & $\begin{array}{l}345^{\star} \\
291\end{array}$ & 1455 & $\begin{array}{l}293^{*} \\
248\end{array}$ & & .248 & 1.24 & 367 & 307 \\
\hline 4 & 5 & 1220 & 6100 & $\longrightarrow$ & 100 & 291 & 1455 & 248 & .37 & .295 & 1.48 & 430 & 367 \\
\hline 5 & 6 & 1045 & 6270 & 5270 & 84 & 251 & 1500 & 213 & .38 & .255 & 1.53 & 382 & 326 \\
\hline 6 & 6 & 1045 & 6270 & - & 100 & 251 & 1500 & 273 & .38 & .304 & 1.82 & 456 & 387 \\
\hline 7 & 10 & 685 & 6850 & 5850 & 85.4 & 167 & 1670 & 142 & .42 & .29 & 2.9 & 484 & 411 \\
\hline 8 & 10 & 685 & 6851 & $\longrightarrow$ & 100 & 167 & 1670 & 142 & .42 & .336 & 3.36 & 561 & 476 \\
\hline 9 & 20 & 370 & 7400 & 6400 & 86.5 & 91 & 1820 & 77.4 & $i^{50}$ & .346 & 6.9 & $8 \div 626$ & 534 \\
\hline 10 & 20 & 370 & $740 J$ & $\longrightarrow$ & 100 & .91 & 1820 & 77.4 & .50 & .4 & 8.0 & 727 & 620 \\
\hline
\end{tabular}

- Predicted Max Vital load during loss of Commercial Power Outage during LOC

$(x)=$ Column No.

Rev. B

Page 7 of 13

LTR $1310-8$ 
iDAHO NATIONAL ENGINEERING LABORATORY

FOAM INEL-1592
(AOV. 4-76)

CALCULATION WORK SHEET
LTR 1310-8

Rev. B .

Page 8 of 13

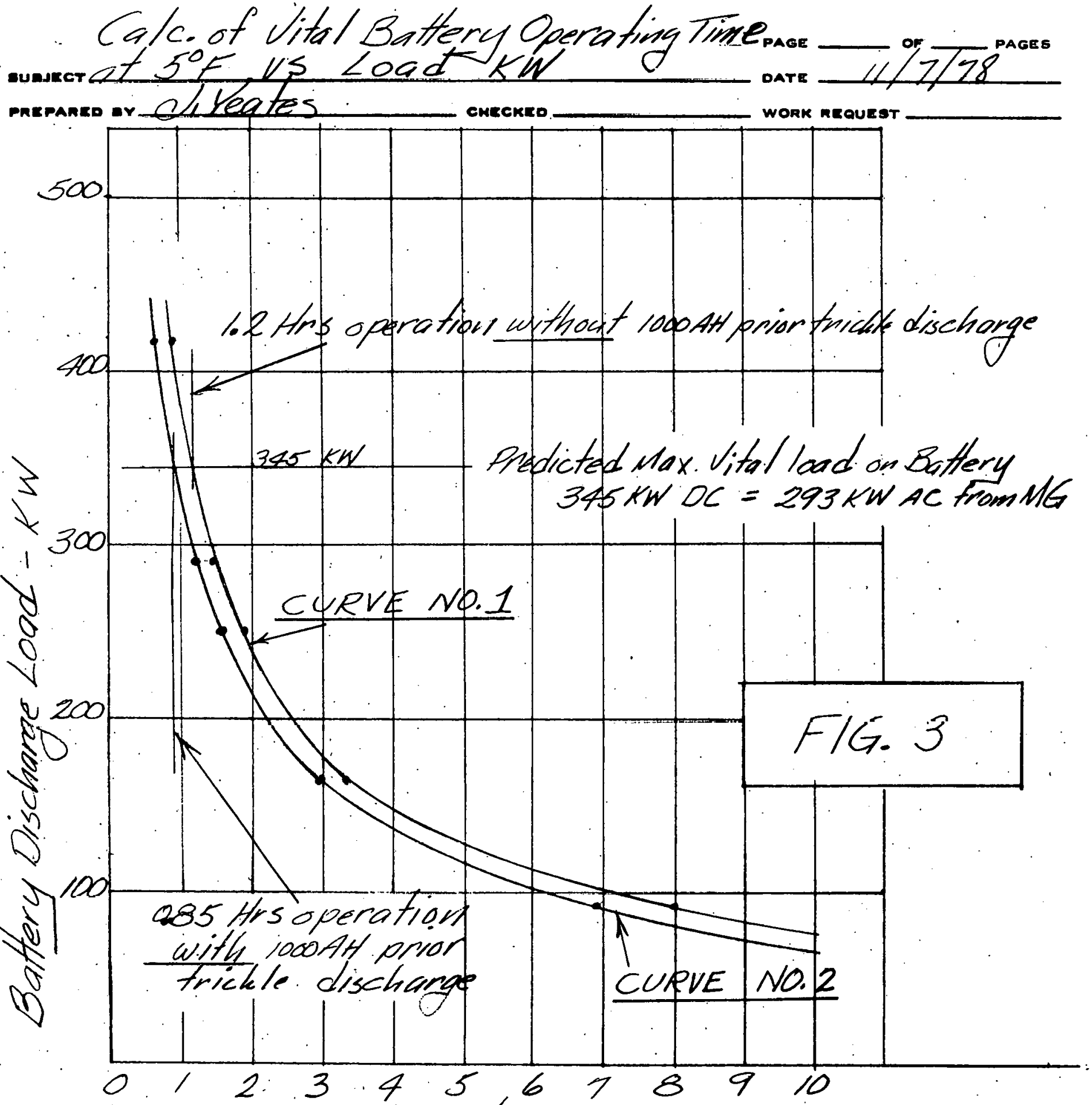

Hours

Time of Battery Discharge to Ra ted Min. Cell Volts

At 5 ole 5

Note: Data points are calculated in Table I, Col. ll. 
IDAHO NATIONAL ENGINEERING LABORATORY

AEROJET NUCLEAR COMPANY

CALCULATION WORK SHEET
LIR $1310-8$

Page 9 of 13

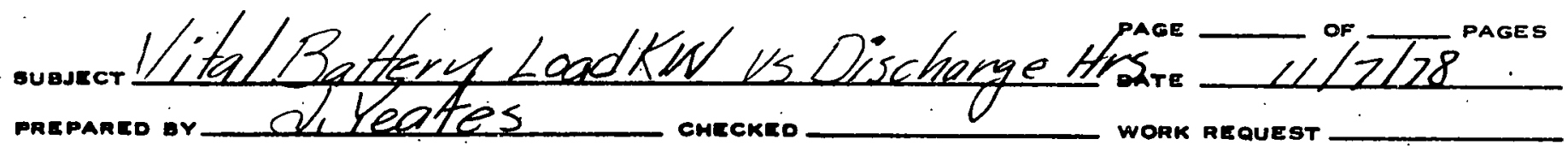

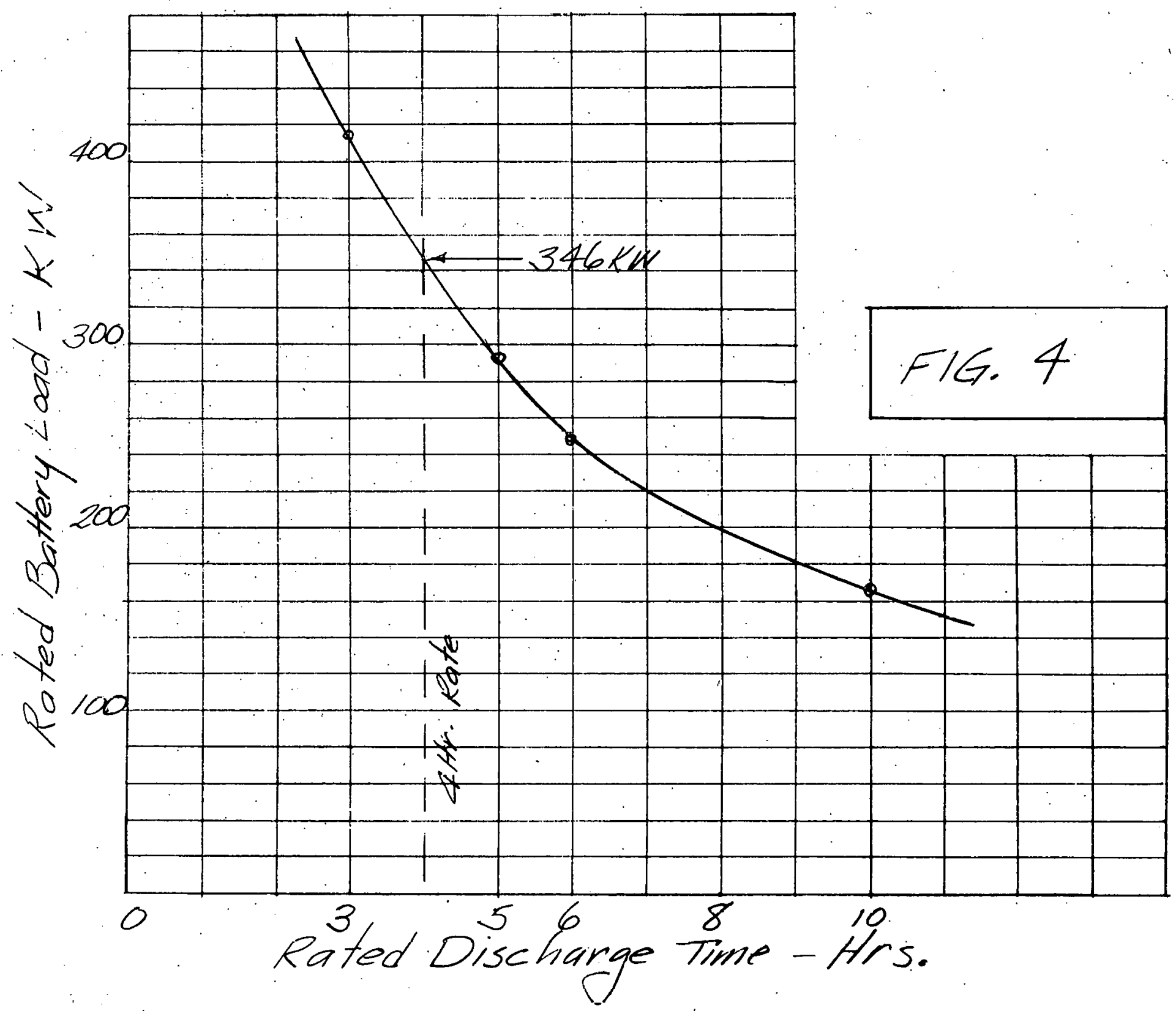

All data is rated of $77^{\circ} \mathrm{F}$ 
LTR 1310-8

Rev. B

Page 10 of 13

\section{REFERENCES}

1. NAVSHIPS 0962-000-4000

Service Manual Type GNX-33

US Submarine Main Storage Battery

Gould National Batteries, Inc.

2. LTR 1310-13

LOFT Vital Bus System Load Study

R. A. Borgen, December 1976

3. LOFT Technical Specifications 
LTR 1310-8

Rev. $B$

Page 11 of 13

APPENDIX A

TECHNICAL ARTICLE "EFFECT OF TEMPERATUURE:

ON BATTERY CAPACITY" 


\section{EFFECT OF TEMPERATURE ON BATTERY CAPACITY}

Since the storage battery is an electrochemical device, the capacity to produre electricity is affected by temperature. The battery ratings in Tables $I$ and $I I$ are generally expressed as at 1.210 full charge specific eravity and for a temperature $7^{\circ} \mathrm{F}$. $\left(25^{\circ} \mathrm{C}\right)$. For lower battery temperatures the ratings must be reduced: for higher battery temperatures. ardditional capacity may be obtained.

The effect of temperature vaties with the discharge rate and to some extent with differeit t! pes and sizes of cells, but for practical purposes the family of curves in Draw, ings EB.6.91 and EB-6792 are considered as typical of the batteries in this Bulletin.

EB.6791 illustrates how the ampere ratings should be corrected. leaving the time periods unchanged. As an example, at $32 \%$., the rating per positive plate for the one minute period to 1.75 voits per cell, is reduced to $6 \% \%$ of the $\pi T \cdot F$. rating.

EB-0792 illustrates how the time period should be cor. rected with the ampere ratings unchanged. As an example, at $40 \%$ f, the 3 hour period would he reduced to $67.5 \%$ for to $67.5 \times 3=1.93$ hours।. with the ampere rating un. changed. Vite that this rurve has no information for the one minute period. an the characteristic volt-time curve for a whe: minute dir-h.1 „2 i page 201 does not lend itself i) making the corren it in the time period. For the one minute corretion, $\mathrm{J}[\{,-)$,$] should be used.$

When determinin: the size of the battery 1 page 51 . if battery operating temperatures below $77^{7} \mathrm{~F}$.. will occur. reductions in the rating - pmer pusitive should be employed in the calculations. While sune increase in capacity occurs " ith hattery temperatures above $77^{2} \mathrm{~F}$.. this is gen. erally tou smatil for consideration in the sizing of the battery.

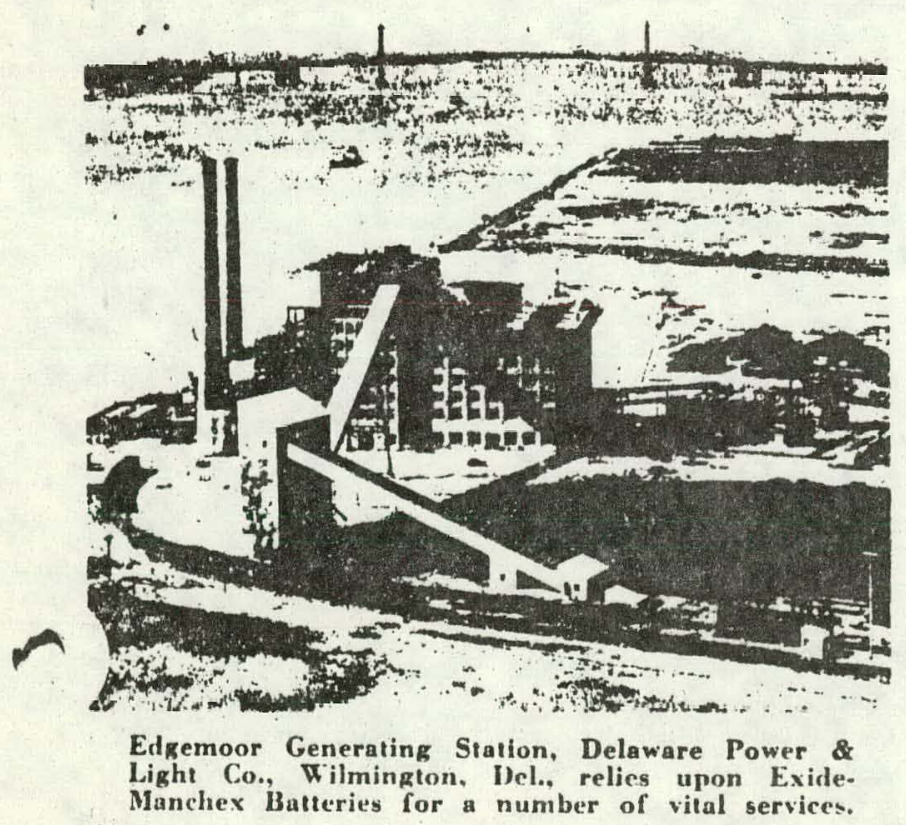

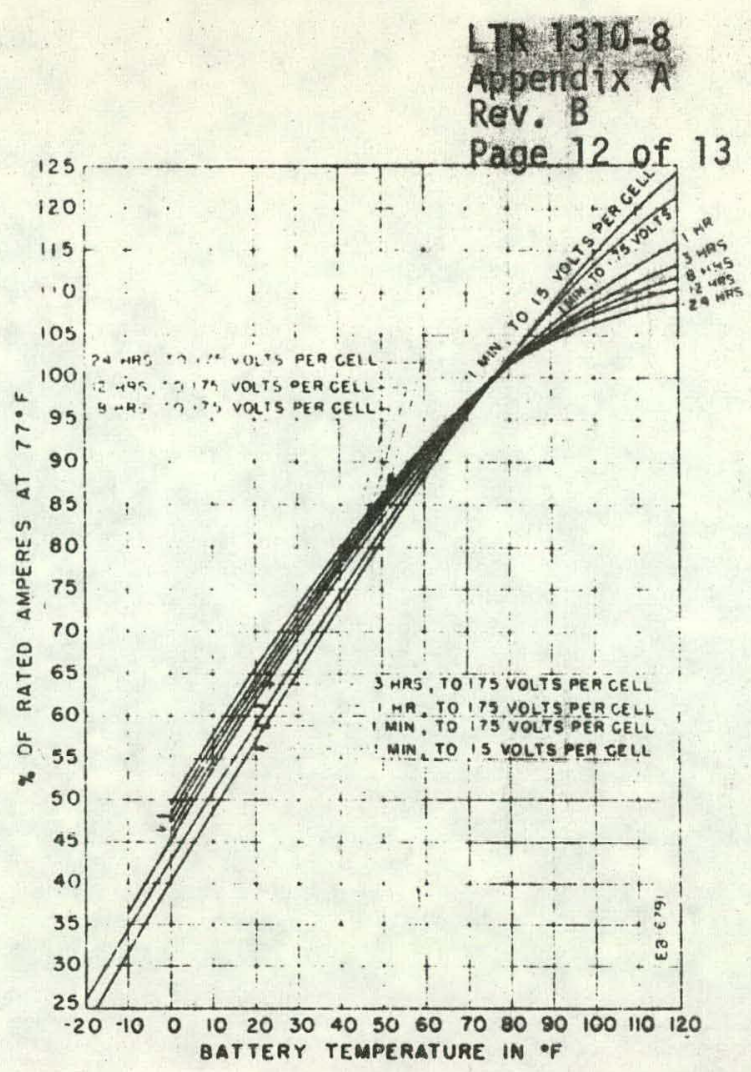

EB.6791

The preceding correction curves are to a fual voltage of $1.75 \mathrm{vic}$ ( volts per cell). For the 8 hours discharge rate. this is a point of its volt time curve where the voltage liegins to fall rather quickly. This is called the "knee of the curve." However when discharging at higher rates. the "knee of the curve" is at an inherent lower voltage. For the one hour rate. it is $1.60 \mathrm{vpc}$. From the practical or user viewpoint, this means that at the hicher rates as 1 min., 1 or 3 hour, that there is no abrupt exhaustion of battery capacity at $1.75 \mathrm{vpc}$, but rather a slow tapering off of the voltage.

The preferred battery room temperature is in the range 60 to $90^{\circ} \mathrm{F}$., for the benefit of the battery, the mainte. nance personnel, and the charger performance. Where battery rom temperatures would average above $90^{\circ}$ more than thirty days in the year, and a few days when the average temperature is below $40^{\circ} \mathrm{F}$., one should consider using the battery with a full charge gravity of 1.170 (1.160-1.180). Ratings for this gravity are available at both $77^{\circ} \mathrm{F}$ and $100^{\circ} \mathrm{F}$. Longer battery life will be obtained with 1.170 full charge gravity at these "tropiçal" temper. atures. The floating voltage suggested for $1.1 \% 0$ cells is 2.12 volts instead of the higher voltage values for 1.210 batteries shown on page 17 .

Slush ice will begin to form in the electrolyte, depend. ing on its specific gravity, as shown below.

$\begin{array}{cc}\text { Specific Gratity } & \text { Freezing Point (Slush) } \\ 1.200 & 16^{\circ} \mathrm{F} . \\ 1.175 & -4^{\circ} \mathrm{F} \\ 1.150 & +5^{\circ} \mathrm{F} .\end{array}$




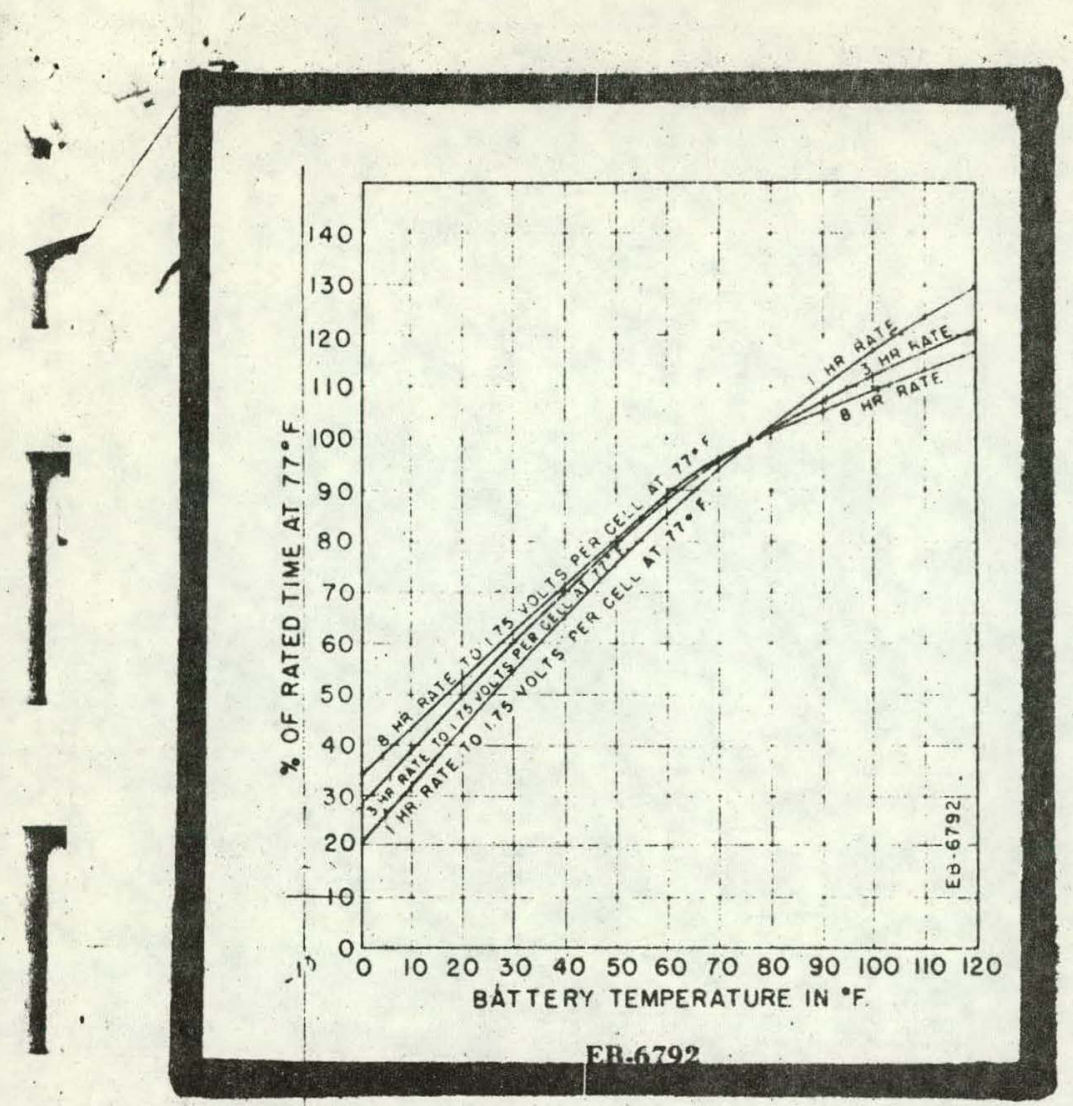

It is the water in the electrolyte that freezes first, leaving the remaining electrolyte with a higher acid content or gravity, and thereby adding a plus factor of safety in this low temperature analysis. Consider further that the specific gravity in a cell lowers during discharge, how much it lowers or the "points drop" for the ampere hours of the 8 hour rating is shown in the instruction book for each cell type. The specific gravity rises again on charge, but in engineering low temperature jobs, if a battery is

A portion of a 60-cell Type E-7 Exide Battery installed in the Lesperance Street Substation of the Union Electric Co., St. Louis, Mo., in November 1926.
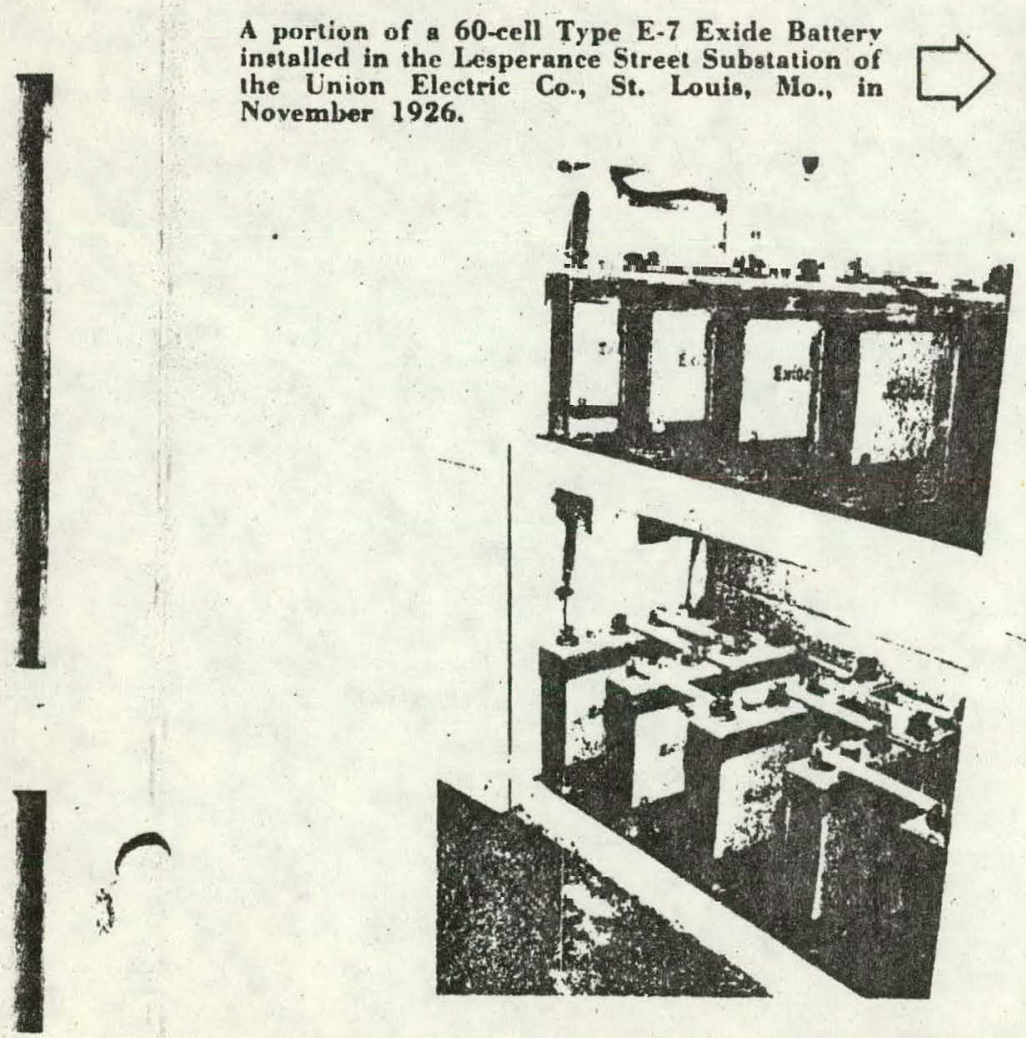

LIK ISIU-C

Appendix A

Rev: B

Page 13 of 13

to stand discharged, with no charging current, in a low temperature situation, the possibility of freezing at lower gravity values should be recognized in sizing the battery. Where chargcing current is available, this has a small heating effect, and freezing of batteries in switchgear applications is a rarity.

Batteries cuuld be produced with a highex full charge gravity than 1.210 in order to meet a low temperature condition. but it is recommended that heating of the battery compartment or room be done instead. [Batteries located in wells below the ground surface have success. fully operated in very low ambient temperatures without heating equipment.

Very low temperatures may also affect the amount of power required to operate out-door switching equipment. Such installations require special consideration.

\section{HOW TO SELECT BATTERY RACKS}

Good maintenance. su important to a storage battery's welfare, is encouraged by the ease with which the periodic voltage tests, the specific gravity lests, and the cell tem. perature readings can be taken. Cells mounted on racks are easier to maintain and keep clean. The periodic adding of water can be done quickly and easily when all cells are located within reach at a convenient height.

Exide four basic type steel racks as shown in tables IV and $\mathrm{V}$ are extremely adaptable. They fit into almost any size or shape of floor space. The rarks are shipped un. assembled, with complete instructions fur easy installa. tion. Racks especially designed for earthquake protection are available upon request.

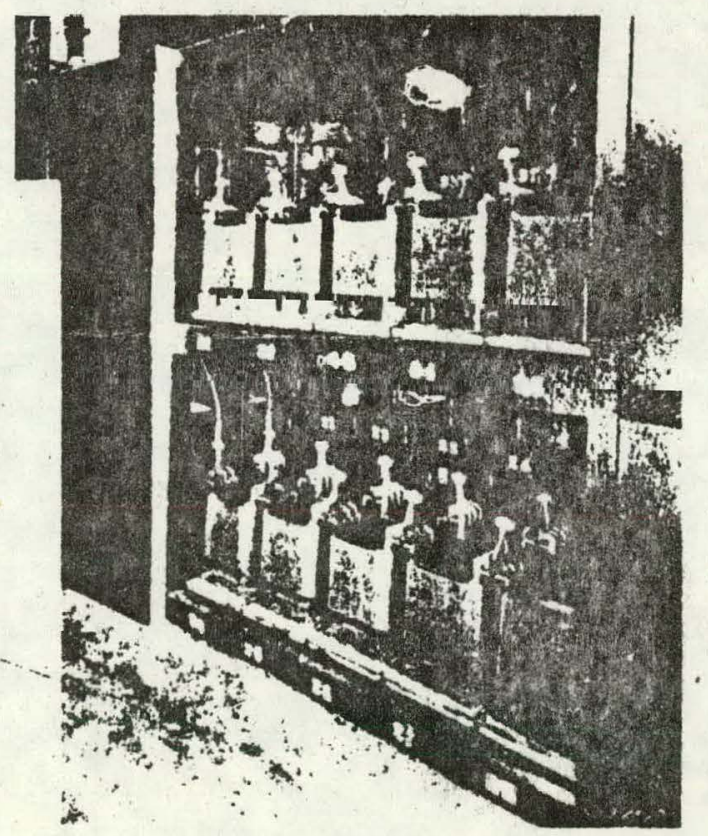

In 1957, after 31 years of dependable service, Exide Battery Type E-7 (above) was replaced by 60 cells of this modern trim-looltings Exide Battery Iype EMP.7. 


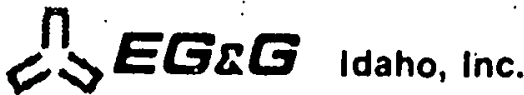

LOFT TECHNICAL REPORT

LOFT PROGRAM

FORM EGBG-229

(Rev 12-76)

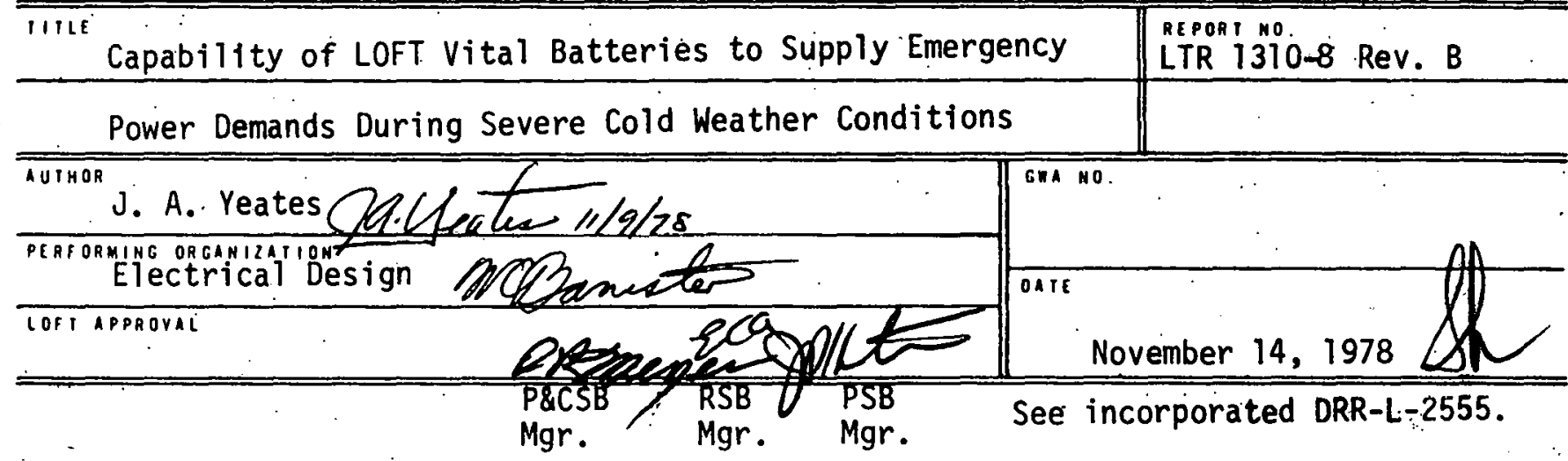

ABSTRACT

This study evaluates the capability of the vital batteries (PPS) to provide electrical power via the vital $D C-A C$ motor generator sets to the LOFT PPS loads during severe cold weather conditions. It is concluded that these batteries while at a temperature of $5^{\circ} \mathrm{F}$ will supply the necessary PPS electrical loads for a time in excess of the one hour permitted to sto the diesel generators and are, therefore, adequate at this temperature.

This Revision B of the LTR includes revioed, more recent, and complete technical data relating to. MG set efficiency, battery operating procedures and cold temperature derating. Revision $B$ supersedes and replates all previous issues. 